\title{
IMPLEMENTASI KURIKULUM 2013 \\ DALAM PEMBELAJARAN BAHASA INDONESIA BERBASIS TEKNOLOGI INFORMASI DAN KOMUNIKASI
}

\author{
Novia Winda \\ STKIP PGRI Banjarmasin \\ Email: Winda_albanjari05@yahoo.com
}

\begin{abstract}
ABSTRAK
Salah satu tuntutan ideal Kurikulum 2013 adalah pemanfaatan TIK untuk meningkatkan efesiensi dan efektivitas pembelajaran.Pemanfaatan TIK terintegrasi dengan semua mata pelajaran sebagai sarana dan media pembelajaran. Kedudukan TIK dalam pembelajaran antara lain: (a) Mempermudah kerjasama pendidik dan peserta didik serta menghilangkan batasan ruang, jarak, dan waktu, (b) Berbagi informasi (sharing information) sehingga mempercepat perkembangan ilmu pengetahuan, dan (c) Menyediakan pembelajaran yang mudah diakses oleh banyak orang (virtual school), berisi berbagai informasi yang berkaitan dengan sekolah.

Bahasa Indonesia sebagai penghela mata pelajaran lain (carrier of knowledge), jumlah jam pengajarannya ditambahkan pada jenjang pendidikan menengah pertama. Mengingat bertambahnya beban mengajar guru Bahasa Indonesia, hadirnya TIK sebagai sarana dan media pembelajaran akan memudahkan proses pembelajaran tersebut. Penambahan beban ini dilakukan karena materi pembelajaran Bahasa Indonesia dianggap menujang memecahkan masalah kehidupan atau mencapai tujuan dalam dunia nyata dengan menggunakan teks sebagai alat utama komunikasi.

Implementasi pembelajaran Bahasa Indonesia berbasis TIK mampu diterapkan dalam keterampilanberbahasa, seperti menyimak, berbicara, membaca, menulis, dan pembelajaran apresiasi sastra.
\end{abstract}

\section{LATAR BELAKANG}

Pendidikan merupakan bidang yang sangat mendasar dan strategis dalam upaya memajukan suatu bangsa. Kini kualitas pendidikan kita (Indonesia), belum memadai, maka perlu/mendesak untuk ditingkatkan. Menurut Anatole France (1817 - 1895, pemenang Nobel Sastra, Prancis) pendidikan bukan cuma urusan memperbanyak isi memori otak atau mencari tahu sesuatu yang tidak diketahui sebelumnya. Namun, lebih dari itu adalah upaya menghubungkan semua yang sudah diketahui dengan hal-hal yang masih menjadi misteri.

Proses pendidikan yang mengandalkan tatap muka saja merupakan sistem pengajaran tradisional yang berjalan lambat dan tidak seiring dengan perkembangan zaman. Sejak ditemukannya media komunikasi multimedia, sudah selayaknya teknologi informasi dan komunikasi (TIK) sebagai basis pembelajaran yang mutakhir. Program pembangunan pendidikan yang terpadu dan terarah berbasis teknologi akan mendorong komunitas pendidikan untuk apresiatif dan proaktif dalam maksimalisasi potensi pendidikan dan memberikan kesempatan 
yang luas kepada peserta didik untuk memperoleh berbagai hal yang diperlukan untuk menunjang proses pendidikan.

Dalam dokumen paparan Wakil Menteri Pendidikan dan Kebudayaan R.I Bidang Pendidikan, tentang Konsep dan Implementasi Kurikulum 2013, disebutkan bahwa Konsekuensi implementasi kurikulum 2013 adalah pengintegrasian mata pelajaran TIK. Mata pelajaran TIK diintegrasikan ke dalam semua mata pelajaran. Dengan kata lain, kurikulum 2013 mensyaratkan penggunaan TIK sebagai sarana dan media pembelajaran untuk semua mata pelajaran.

Pada Kurikulum 2013 Kemendikbud menempatkan Bahasa Indonesia sebagai penghela mata pelajaran lain (carrier of knowledge), sehingga mata pelajaran Bahasa Indonesia jam pelajarannya ditambahkan pada jenjang pendidikan menengah pertama. Mengingat bertambahnya beban mengajar guru Bahasa Indonesia, hadirnya TIK sebagai sarana dan media pembelajaran akan memudahkan proses pembelajaran tersebut.

\section{PEMBAHASAN}

\section{Kurikulum 2013}

Kurikulum 2013 (K-13) menurut Wikipedia (online) merupakan kurikulum pengganti Kurikulum Tingkat Satuan Pendidikan (KTSP), sedangkan menurut Priyatni (2014) Kurikulum 2013 adalah penyempurnaan dan penguatan dari Kurikulum Tingkat Satuan Pendidikan (KTSP). Dengan demikian Kurikulum 2013 merupakan kurikulum terbaru dalam dunia pendidikan di Indonesia setelah Kurikulum Tingkat Satuan Pendidikan (KTSP).

Salah satu aspek yang disempurnakan dalam kurikulum 2013 adalah standar kompetensi lulusan (SKL).SKL adalah kriteria mengenai kualifikasi kemampuan lulusan yang mencakup sikap, pengetahuan, dan keterampilan (Salinan Lampiran Permendikbud No 54 Tahun 2013). SKL merupakan acuan utama pengembangan standar isi, standar proses, standar penilaian pendidikan, standar pendidik dan tenaga kependidikan, standar sarana dan prasarana, dan standar pengelolaan, serta standar pembiayaan (dalam Ismawati).

Priyatni (2014: 95) menyatakan untuk mencapai ketiga kompetensi pada kurikulum 2013, pembelajaran harus dilaksanakan dengan tuntutan ideal berikut (Permendikbud, Nomor 65 Tahun 2013 tentang Standar Proses).

1. Dari peserta didik diberi tahu menuju peserta didik mencari tahu.

2. Dari pendidik sebagai satu-satunya sumber belajar berbasis aneka sumber.

3. Dari pendekatan tekstual menuju pendekatan proses.

4. Dari pembelajaran berbasis konten menuju pembelajaran berbasis kompetensi.

5. Dari pembelajaran parsial menuju pembelajaran terpadu.

6. Dari pembelajaran yang menekankan jawaban tunggal menuju jawaban multidimensi.

7. Dari pembelajaran verbalisme menuju pembelajaran aplikatif.

8. Peningkatan dan keseimbangan antara hardskills dan softskill.

9. Pembelajaran yang mengutamakan pembudayaan dan pemberdayaan peserta didik sebagai pembelajar sepanjang hayat. 
10. Pembelajaran yang menerapkan nilai-nilai Ing ngarso sung tulodo, Ing madya mangun karso, tut wuri handayani.

11. Pembelajaran berlangsung di rumah, di sekolah, dan di masyarakat.

12. Pembelajaran yang menerapkan prinsip siapa saja adalah pendidik, peserta didik, dan di mana saja adalah kelas.

13. Pemanfaatan TIK untuk meningkatkan efesiensi dan efektivitas pembelajaran.

14. Pengakuan atas perbedaan individu dan latar belakang budaya peserta didik.

\section{Kurikulum Bahasa Indonesia 2013}

Kompetensi dasar (KD) mata pelajaran Bahasa Indonesia kurikulum 2013 untuk jenjang SD dapat dilihat dalam Salinan Permendikbud Nomor 67 Tahun 2013 tentang Kerangka Dasar dan Struktur Kurikulum SD. KD mata pelajaran Bahasa Indonesia kurikulum 2013 untuk jenjang SMP dapat dilihat dalam Salinan Permendikbud Nomor 68 Tahun 2013 tentang Kerangka Dasar dan Struktur Kurikulum SMP. KD mata pelajaran Bahasa Indonesia kurikulum 2013 untuk jenjang SMA/Aliyah dapat dilihat dalam Salinan Permendikbud Nomor 69 Tahun 2013 tentang Kerangka Dasar dan Struktur Kurikulum SMA/Aliyah. KD mata pelajaran Bahasa Indonesia kurikulum 2013 untuk jenjang SMK dapat dilihat dalam Salinan Permendikbud Nomor 70 Tahun 2013 tentang Kerangka Dasar dan Struktur Kurikulum SMK (dalam Priyatni, 2014: 23-24).

Ruang lingkup kompetensi dasar mata pelajaran Bahasa Indonesia terbagi menjadi 3 menurut Priyatni, yakni ranah sikap, ranah pengetahuan, dan ranah keterampilan.Kompetensi Dasar (KD) ranah sikap terbagi menjadi ranah spiritual dan sosial.KD pada ranah spiritual untuk jenjang SMP dan SMA fokus pada perwujudan rasa syukur terhadap keberadaan bahasa Indonesia (sebagai alat pemersatu bangsa, sebagai sarana untuk memahami dan sekaligus menyajikan informasi secara lisan dan tertulis).KD ranah sikap spiritual ini tidak diajarkan, tetapi diintegrasikan dalam KD ranah kognitif dan psikomorik.

Ranah sikap aspek sosial mata pelajaran Bahasa Indonesia berbeda di tiap kelas.KD ini fokus pada karakter jujur, peduli, cinta tanah air, semangat kebangsaan, demokratis, kreatif, santun, percaya diri ketika melakukan aktivitas berbahasa baik secara lisan maupun tulisan.

Ranah pengetahuan dan ranah keterampilan dalam kurikulum 2013 pembelajaran yang dilaksanakan adalah pembelajaran berbasis teks.Hal ini berangkat dari asumsi bahwa fungsi pembelajaran bahasa adalah mengembangkan kemampuan memahami dan menciptakan teks.Kemampuan memahami dan menciptakan teks ini berdasarkan fakta bahwa kita hidup dalam dunia kata-kata.

Menurut Puskur dalam Priyatni kompetensi literasi adalah kompetensi inti pembelajaran Bahasa Indonesia dalam memecahkan masalah kehidupan.Kemampuan menyelesaikan masalah atau mencapai tujuan dalam dunia nyata dengan menggunakan teks sebagai alat utama komunikasi.

Kompetensi literasi merupakan integrasi dari keterampilan menyimak, berbicara, membaca, menulis, dan berpikir kritis. Sehingga pembelajaran Bahasa Indonesia akan meningkatkan kemampuan peserta didik dalam: (1) komunikasi 
efektif, (2) melakukan inkuiri, (3) berbagi informasi, (4) mengekspresikan ide, dan (5) memecahkan berbagai persoalan kehidupan secara lebih bermakna.

Materi pokok pembelajaran Bahasa Indonesia diarahkan pada penguasaan beragam jenis teks. Dalam satu tahun peserta didik diajak memahami dan memproduksi minimal lima jenis teks terpilih secara utuh dan tuntas. Kemudian peserta didik diajak mengontruksi dan mendekontruksi teks-teks tersebut.Kegiatan ini dimaksudkan agar peserta didik mengalami, memahami, mampu membedakan, menganalisis, mengevaluasi, menyusun, menelaah, dan menyunting teks-teks tersebut.

Pada KD kognitif, peserta didik dituntut untuk memahami jenis-jenis teks, sedangkan pada KD keterampilan, peserta didik diharapkan mampu memproduksi jenis-jenis teks tertentu secara utuh dan bermakna baik lisan maupun tertulis.

\section{Teknologi Informasi dan Komunikasi}

Teknologi informasi dan komunikasi (TIK) adalah terjemahan dari information and communication technology (ICT) yang dapat diartikan sebagai teknologi yang berfungsi atau yang dapat dimanfaatkan untuk mendukung komunikasi atau penyampaian informasi (Hartoyo, 2010: 4). Lebih lanjut, Kent County Council (dalam Hartoyo, 2010: 8) mendefinisikan TIK sebagai cara, media, atau teknologi untuk menyimpan, mengembalikan, memanipulasi, meneruskan, dan menerima data atau informasi digital. Secara singkat TIK dapat didefinisikan sebagai teknologi yang berguna untuk mendukung proses komunikasi atau penyampaian informasi dari pengirim ke penerima informasi.

Beberapaalat yang dapat digolongkan sebagai teknologi informasi dan komunikasi (TIK) antara lain: televisi, komputer, sound system, telepon, faximill, pager, push ti talk, multimedia interaktif, MIDI, social interface, dan internet.

1) Televisi merupakan alat yang dapat mentransmisikan sinyal-sinyal elektrik dan menampilkannya pada sebuah layar elektronik sehingga menghasilkan gambar dan suara.

2) Komputer merupakan perangkat elektronik yang memiliki kemampuan untuk menerima dan mengolah data secara cermat.

3) Sound system perangkat elektronik yang dirancang untuk menghasilkan suara yang bagus, dengan efek bass yang mantap.

4) Telepon adalah alat telekomunikasi yang dapat mengirimkan pembicaraan melalui sinyal listrik. Bahkan saat ini telah berkembang pesat telepon genggam, biasanya disebut juga dengan cellular yang merupakan pengembangan telepon biasa, di mana perangkatnya dapat digunakan sebagai perangkat untuk mobile atau berpindah-pindah.

5) Faximill diisingkat dengan faks, merupakan alat elektronik untuk mengirimkan dokumen dari satu tempat ke tempat lain melalui Internet.

6) Pager adalah alat panggil seperti handphone, namun lebih praktis karena hanya memiliki fasilitas menerima sms.

7) Push to talk adalah alat bicara yang ukuran tubuhnya kecil yang cara pemakaiannya bergantian dengan lawan bicaranya. 
8) Multimedia interaktif adalah teknologi yang memadukan dua media atau lebih seperti teks, grafik, audio, gerak, video statis, atau animasi, hingga menjadi aplikasi berbasis komputer.

9) MIDI adalah singkatan Musical Instrument Digital Interface yaitu interface instrumen musik digital yang memungkinkan pengguna untuk mengakses melalui komputer sehingga menghasilkan suara yang lebih baik.

10) Social interface adalah media yang menyediakan fasilitas untuk berinteraksi antara manusia dengan komputer secara lebih intuitif dan mudah melalui tulisan, suara, sentuhan, gerak mata, dan bahasa tubuh.

11) Internet (kependekan dari 'inter-network') ialah sebuah sistem informasi global berbasis komputer yang terdiri atas beberapa jaringan komputer yang saling berhubungan.

Seiring dengan perkembangan teknologi, TIK didukung dengan sistem komputer jaringan yang memungkinkan orang berkomunikasi secara tatap muka dan mendengar suara secara langsung, walaupun mereka tidak berada pada tempat yang sama. Dengan TIK penyampaian informasi dapat dilakukan secara langsung dan tidak langsung antara komunikator dengan komunikan.

\section{Prinsip-Prinsip Integrasi TIK dalam Pembelajaran}

Menurut Nadhifah terdapat 9 (sembilan) prinsip integrasi TIK dalam pembelajaran, antara lain:

(a) Aktif ialah memungkinkan siswa dapat terlibat aktif dengan proses belajar yang menarik dan bermakna;

(b) Konstruktif ialah memungkinkan siswa dapat menggabungkan ide-ide baru kedalam pengetahuan yang telah dimiliki sebelumnya untuk memahami makna atau keingintahuan dan keraguan yang selama ini ada dalam benaknya;

(c) Kolaboratif ialah memungkinkan siswa dalam suatu kelompok atau komunitas yang saling bekerjasama, berbagi ide, saran, atau pengalaman, menasehati, dan memberi masukan untuk sesama anggota kelompoknya;

(d) Antusias ialah memungkinkan siswa dapat secara aktif dan antusias berusaha untuk mencapai tujuan yang diinginkan;

(e) Dialogis ialah memungkinkan proses belajar secara inherent merupakan suatu proses sosial dan dialogis dimana siswa memperoleh keuntungan dari proses komunikasi tersebut baik di dalam maupun luar sekolah;

(f) Kontekstual ialah memungkinkan situasi belajar diarahkan pada proses belajar yang bermakna;

(g) Reflektif ialah memungkinkan siswa dapat menyadari apa yang telah ia pelajari serta merenungkan apa yang telah dipelajari sebagai bagian dari proses belajar itu sendiri;

(h) Multisensory ialah memungkinkan pembelajaran dapat disampaikan untuk berbagai modalitas belajar seperti audio, visual, dan kinestetik; dan

(i) High Order Thinking Skills Trainingialah 101 Cara Siswa Belajar Aktif.

\section{Manfaat Teknologi Informasi dan Komunikasi}


Dalam konteks pembelajaran, TIK berperan sebagai jembatan antara guru dengan siswa dalam melakukan proses pembelajaran. TIK juga dapat bertindak sebagai guru atau tutorial. Selain itu TIK juga dapat menjadi buku referensi yang tak terbatas dan dapat diakses di mana pun serta kapan pun. Jika dikombinasikan dengan media lain contohnya video, TIK dapat berperan sebagai teman bagi siswa dalam permainan edukatif.Fitzpark dan Davies (dalam Hartoyo, 2010: 54-58) menguraikan delapan cara menggunakan TIK dalam media pembelajaran, yaitu presentasi, latihan, authoring, Computer Aided Asessment (CAA), rujukan, penerbitan, komunikasi, dan simulasi.

Kedudukan TI dalam pembelajaran antara lain: (a) Mempermudah kerjasama pendidik dan peserta didik serta menghilangkan batasan ruang, jarak, dan waktu, (b) Berbagi informasi (sharing information) sehingga mempercepat perkembangan ilmu pengetahuan, dan (c) Menyediakan pembelajaran yang mudah diakses oleh banyak orang (virtual school), berisi berbagai informasi yang berkaitan dengan sekolah.

Adapun manfaat IT bagi bidang pendidikan antara lain:

a. akses ke perpustakaan.

b. akses ke pakar.

c. Melaksanakan pembelajaran secara online.

d. Menyediakan layangan informasi yang berhungan dengan sekolah.

e. Menyediakan fasilitas pencari data.

f. Menyediakan fasilitas diskusi dan kerjasama.

\section{Implementasi Pembelajaran Bahasa Indonesia Berbasis TIK}

Adapunbeberapa contoh pengembangan TIK sebagai media pembelajaran Bahasa Indonesia berdasarkan empat aspek keterampilan berbahasa dan apresiasi sastra:

1. TIK sebagai Media Pembelajaran Aspek Menyimak

Dalam pembelajaran menyimak, media yang digunakan yaitu radio, tape recorder, atau televisi. Contoh: Guru membacakan satu cerita dari sebuah wacana, siswa mendengarkan dan dapat menceritakan kembali cerita tersebut dengan bahasanya sendiri. Siswa menceritakan pengalamannya saat liburan yang lain mendengarkan radio, siswa diberi tugas mendengarkan berita, drama, dan radio. Dengan tape recorder guru dapat memperdengarkan rekaman puisi, drama, pidato, dan lain-lain yang berkaitan dengan materi yang diajarkan. Dengan media TV, guru juga dapat menugaskan siswa untuk menyimak wawancara, dialog, atau pun berita, kemudian mempresentasikan hasil simakannya di depan kelas.

2. TIK sebagai Media Pembelajaran Aspek Berbicara

Guru menyiapkanpower point yang berisi beberapa gambar dan kartu yang berisi kata-kata ungkapan yang berbubungan dengan gambar yang ditayangkan melalui $L C D$. Kemudian siswa disuruh bercerita dengan menggunakan kata ungkapan yang diperoleh dari kartu atau gambar tersebut. Siswa juga dapat menceritakan isi gambar yang dipasang di depan kelas secara sistematis sehingga menjadi satu cerita yang utuh.

3. TIK sebagai Media Pembelajaran Aspek Membaca 
Sebuah wacana dipotong menjadi penggalan-penggalan, yang kemudian paragrafnya diacak ditayangkan melalui $L C D$. Setelah itu siswa disuruh menyusun kembali menjadi wacana utuh kemudian siswa membaca wacana tersebut sesuai dengan butir pembelajaran yang diajarkan.

4. TIK sebagai Media Pembelajaran Aspek Menulis

Dalam pembelajaran menulis media yang dapat digunakan yaitu: gambar, benda, kartu gambar, dan $L C D$. Guru memperlihatkan gambar seri melalui $L C D$ kemudian siswa ditugasi menceritakan rangkaian gambar tersebut secara tertulis. Sebuah film dapat dijadikan bahan oleh siswa untuk menulis sebuah cerita.

\section{TIK sebagai Media Pembelajaran Apresiasi Sastra}

Rekaman drama, puisi, dan cerpen dapat diperdengarkan kepada siswa. Sehingga siswa diharapkan dapat memahami unsur intrinsik dan ekstrinsik dalam karya sastra tersebut. Video pembacaan puisi juga bisa diperdengarkan kepada siswa, sehingga siswa diharapkan mampu mengapresiasi puisi tersebut.

\section{KESIMPULAN}

Konsekuensi implementasi Kurikulum 2013 adalah pengintegrasian mata pelajaran TIK.Mata pelajaran TIK diintegrasikan ke dalam semua mata pelajaran. Dengan kata lain, kurikulum 2013 mensyaratkan penggunaan TIK sebagai sarana dan media pembelajaran untuk semua mata pelajaran.Pada Kurikulum 2013 Kemendikbud menempatkan Bahasa Indonesia sebagai penghela mata pelajaran lain (carrier of knowledge), sehingga mata pelajaran Bahasa Indonesia jam pelajarannya ditambahkan pada jenjang pendidikan menengah pertama. Mengingat bertambahnya beban mengajar guru Bahasa Indonesia, hadirnya TIK sebagai sarana dan media pembelajaran akan memudahkan proses pembelajaran tersebut.

Kompetensi literasi adalah kompetensi inti pembelajaran Bahasa Indonesia pada Kurikulum 2013 dalam memecahkan masalah kehidupan.Kemampuan menyelesaikan masalah atau mencapai tujuan dalam dunia nyata dengan menggunakan teks sebagai alat utama komunikasi.Kompetensi literasi merupakan integrasi dari keterampilan menyimak, berbicara, membaca, menulis, dan berpikir kritis. Sehingga pembelajaran Bahasa Indonesia akan meningkatkan kemampuan peserta didik dalam: (1) komunikasi efektif, (2) melakukan inkuiri, (3) berbagi informasi, (4) mengekspresikan ide, dan (5) memecahkan berbagai persoalan kehidupan secara lebih bermakna.

Kedudukan TIK dalam pembelajaran antara lain: (a) Mempermudah kerjasama pendidik dan peserta didik serta menghilangkan batasan ruang, jarak, dan waktu, (b) Berbagi informasi (sharing information) sehingga mempercepat perkembangan ilmu pengetahuan, dan (c) Menyediakan pembelajaran yang mudah diakses oleh banyak orang (virtual school), berisi berbagai informasi yang berkaitan dengan sekolah. 
Implementasi pembelajaran Bahasa Indonesia berbasis TIK mampu diterapkan dalam keterampilanberbahasa, seperti menyimak, berbicara, membaca, menulis, dan pembelajaran apresiasi sastra.Pemanfaatan TIK untuk meningkatkan efesiensi dan efektivitas pembelajaran merupakan salah satu tuntutan ideal Kurikulum 2013 karena terintegrasi dengan semua mata pelajaran sebagai sarana dan media pembelajaran.

\section{Daftar Pustaka}

Hartoyo.2010. Teknologi Informasi dan Komunikasi (TIK) dalam Pembelajaran Bahasa. Semarang: Penerbit Pelita Insani.

http://fxekobudi.net/opini/konsep-integrasi-tik-dalam-pembelajaran-menurutunesco-vs-integrasi-mata-pelajaran-tik-di-kurikulum-2013/, diakses pada 27 Februari 2016 pukul 20.00 WITA.

https://indrianatyapermatasari.wordpress.com/tik/pemanfaatan-tik-sebagai-mediapembelajaran-tik-dalam-pembelajaran-bahasa-indonesia/, diakses pada 27 Februari 2016 pukul 20.00 WITA.

http://ejournal.kopertais4.or.id/index.php/modeling/article/view/741, diakses pada 27 Februari 2016 pukul 20.00 WITA.

Ismawati, Esti. 2012. Telaah Kurikulum dan Pengembangan Bahan Ajar. Yogyakarta: Ombak.

Paparan Wakil Menteri Pendidikan dan Kebudayaan bidang Pendidikan.http://kemdikbud.go.id/kemdikbud/dokumen/Paparan/Paparan\% 20Wamendik.pdf.

Peraturan Pemerintah Republik Indonesia Nomor 32 Tahun 2013 Tentang Perubahan Atas Peraturan Pemerintah Nomor 19 Tahun 2005 Tentang Standar Nasional Pendidikan Kurikulum 2013.

Priyatni, Endah Tri. 2014. Desain Pembelajaran Bahasa Indonesia Dalam Kurikulum 2013. Jakarta: Bumi Aksara.

Sadiman, Arief S., R. Rahardjo, Anung Haryono, Rahardjito. 1990. Media Pendidikan: Pengertian, Pengembangan, dan Pemanfaatannya. Jakarta: CV Rajawali.

Suyanto. 2011. Makalah Pembelajaran Bahasa Indonesia Berbasis Teknologi, Informasi, dan Komunikasi. Jakarta: Universitas Muhammadiyah Prof. DR. HAMKA (tidak diterbitkan).

Wikepedia. 2013. Kurikulum 2013. https://id.wikipedia.org/ wiki/Kurikulum_ 2013, diakses pada 10 Desember 2015 pukul 22.00 WITA. 